\title{
Implementation of Some Didactic Innovations in Teaching and Learning Process
}

\section{Doctorate: Albana Tahiri}

\author{
Specialist in Educations and Sport Ministry, Tirana \\ albanatahiri@gmail.com
}

\section{Doi:10.5901/jesr.2014.v4n2p184}

\begin{abstract}
Recognizing the problems of school related to enhancing the quality of learning, while understanding, thinking, and judging on this field of study we think that teaching innovations are one of the main keys through which can be changed the quality of learning for students at schools. For this reason, this paper is dedicated to improving the quality of student learning in school through implementation of new schemes of teaching, contemporary learning techniques and strategies, research topics, theoretical analysis and practical generalizations. This paper will consider some practical issues of teaching methodology with the main focus on the student, a process which represent a vital practice of student-teacher relationship through which skills, values, deep and sustainable competencies are acquired by students. The practice of teaching focusing on the student has allowed us to promote successful techniques and strategies to achieve specific learning goals, which is reflected in improved quality of learning and students' final scores. Through the models that will be presented in this paper we will prove the effectiveness of the strategies and techniques used during the learning process-on the students. This practice has allowed us to make a selection and a typological classification of these techniques and strategies finding at the same time their right place in the teaching practice, and strongly associating each one of them to the objective it can achieve. Interaction of the technique with specific targets makes the process of teaching to go through the procedural steps and escalates the achievement of the objectives from the lower level to the highest one. The teacher responsibilities have already been seen and should be seen in the new professional contexts which contain in itself creative and inventive skills and competences.
\end{abstract}

Keywords: didactic innovations, teaching methodology, contemporary strategies and techniques.

\section{Introduction}

Teaching and learning today are considered as a significant approach to the structure and content of the curriculum. Nowadays learning can not be considered a unique and independent process from alternative environments where the student has the opportunity to express himself anywhere. Teaching students on the basis of competencies and levels of learning increasingly is emerging globally in education. For students the learning process is almost an architecture, which must be built step by step and should pass from one level to the other through contemporary schemes, strategies and techniques that offer concrete achievement standards (competences).

Working through use of levels, for teachers it is possible nowadays to effectively use teaching and learning strategies by considering the individual needs of the students and focusing the teaching process on students, making him an active participant in the teaching and learning process.

The rapid development of information technology has introduced to the teaching process new learning spaces. A number of problems have emerged which connect didactics with many other disciplines or areas, creating an interaction among subjects, as a basic principle in the learning process.

Recently it has been discussed dynamically on these relationships and about the teaching process. These new relationships and professional features in the teaching profession have been called by Piaget as the essence of education, "the main purpose of education is to create men who are capable of doing new things, not simply repeating what other generations have done, people who are creative, inventive and discoverers" (Piaget, 2005 Tirana)

Finding creative and innovative ways in education today is a matter of increasing the quality and performance of each student. In order to make it more concrete this contemporary concept, in this article we will focus on finding some new teaching spaces, which lead us towards achieving the scope of this paper.

Teaching for learning is an evident approach nowadays in the structure and content of the curriculum. The student passes from one level to another, step by step. Working with levels it is possible for teachers to effectively use teaching and learning strategies by really keeping the spotlight on the student, making him an active participant in the process of teaching and learning methodology. 
For this purpose The National Education Strategy states: "Teaching methodologies in the elementary education include using style and teaching models that ensure students' active participation in the selection and use of information by promoting personal responsibility, initiative, reflection, independence of judgment, self-esteem, cooperation and equality." (MASH, 2012, page 21)

Further in this document another issue is evidenced related to the quality of learning "Teachers and students increase their work to improve the quality of teaching and learning exactly based on the quality of information provided by these judgments. This serves to increase the reliability of assessments of teachers, parents, colleagues and community ... "(MASH, 2012, page 22). For this purpose in connection with the role of teachers in the teaching and learning process Piaget states: "the role of the teacher is to form in the mind of students a tool, a method to allow the latter to understand the world " followed by the phrase "Education is like medicine: an art, which relies - or should be - relied on certain scientific knowledge" (Piaget, 2005, Tirana, page 14)

The methodology used in the paper entitled "Implementation of some didactic innovations in the teaching and learning process" is supposed to highlight his intent in the general practice of the Albanian school regarding the teaching and learning process, a practice that is in the deep process of reform, recognizing the results day by day. Student centered teaching as a progressive movement of recent practice teaching in the Albanian school, based on experimented projects for this purpose such as "Developing critical thinking through literacy" (SOROS, 1997-2004), Global Education, (Unicef 1994- ongoing), Interaction in Class (Save the Children, 2004-2013, etc). Through these projects are provided new teaching and learning practices that have produced results and have become part of the teacher's work.

Teachers in the Albanian schools are employing a whole set of techniques and strategies that enable them to achieve successful teaching practices. Based on this new educational environment we have experimented and used work materials and observations. Also we have contacted teachers and students to support the findings of this paper.

Specifically are being studied all documents obtained from the above project.

- We have analyzed more than 50 teacher's journals to highlight their level of use of new methods related to the teaching process focused on the student.

- We have studied classified and grouped strategies and techniques by the service they provide.

- We have observed lessons and conducted surveys on teachers.

\section{Research Issues}

\subsection{The teaching process focused on the student as a process through which earned values}

The teaching process before the year 1994 (in Albania) was performed according to traditional and classical method, the students in the class listened the teacher while the student would reproduce what he hard from the teacher. In this way the class was a group of individuals where the student was not allowed to have the spirit of cooperation, and where work started with the initiative of the student becoming after it collective, thus creating a closed related social life.

So the students themselves create something deeper, a general education attitude oriented toward global cooperation. Global education requires an overhaul of the entire teaching process. The most important impact of teaching affects the student attitude and vision for its future, in order to feel (or not) as part of the society where he lives.

Referring Michael Fullani "I ask the question: What would happen if we considered the student as a person or entity, whose opinion counts for introducing and implementing reforms in school?" ... "Educational change, on overall, is a phenomenon associated with people connected with each of the individuals as a student. Every educational change, even the education in general, will fail, if (for them) there will not be a meaningful role in this enterprise. "(Fullani, 2001, page 230)

In order that educational changes can include as much as possible the innovation, today more and more the teaching process is oriented toward a contemporary teaching process focused on the student

Goodlat (1984) says that "the teaching process seems to improve when students are active, understand what is expected of them, when their work is evaluated, when they recognize quickly their mistakes and receive instructions for improving their work" (Fullani, 2001, page 236)

In didactics the teaching process is considered as a process that merges "art and science" "Teaching as "art" is based on the teacher's intuition and actions during the process of making the curriculum flexible, accessible, vibrant, and interactive. Teaching as "science" is dictated by the position of the authors of the curriculum and the direction that they have given the subject content in certain subjects." (Gjokuta, 2009, page 263)

If the classic teaching was focused on the teacher and the curriculum, the new teaching process is based primary 
on students leaving the teacher behind. This situation impacts the schools, to implement this reform going from theory to practice by mean of using active school methods.

"If the purpose of education is to form autonomous human beings, then learning based on verbal transmission and authority should disappear. Active school methods are the ones that emphasize the importance of the principles of freedom, of the activity and interest of the child, with the aim to achieve his development" (Piaget, 2005, page 10)

In active methods the behavior relationship created between teachers and students become interactive and affect the personality of students. The teacher is important in children's education. The performance of the learning process depends on the performance that he would consider during the interpretation of the learning process, in which the student should be an active experimenter, seeking and finding solutions. The teacher can facilitate the process by offering opposite suggestions and leads finally in the solution of the problem.

Not in vain in contemporary psychological and pedagogical literature, we read that the teacher should be aware that in addition to learning contents (e.g. scientific knowledge) the teacher uses different voice tones, gestures, movements, etc., that are included in teachers' performance and to what we call the "warmth and enthusiasm" that the teacher uses in class.

The teacher should transform the class in learning and assignment activities including all components of reading, speaking and writing. "Learning time should be seen differently: as a cake which students divide into learning activities between reading, speaking and writing. To succeed in this kind of teaching, the teacher should know very well the individual features of students in regard to their learning styles. "(Gjokuta, 2009, page 266)

The teacher should be demanding and should have a good knowledge of innovative teaching. The teacher should not be a presenter of traditional methods, instead should promote scientific research work based on the idea that in order to understand there should be created simultaneously authors and actors in the implementation of a process. "to become a better teacher, it means having more confidence, when deciding on teaching issues, having as well the commitment to further improve..." (Fullani, 2001, page 194)

Interactive teaching as a concept can be summarized in the form of some didactic terms, which constitute in itself inseparable integrating links of the teaching process. Everything in the class is developed and is done based on the to students' needs and interests.

For this purpose the teacher makes preparation for the organization of the teaching process bringing diverse didactic innovations. The more time spent on the preparation and development of the teaching plan, the greater are the chances for a successful and qualitative work in teaching and learning process.

The teacher, in order to be successful in achieving the teaching class, should be careful in drafting a functional structure which helps the teaching process, considering at the same time that for each phase he should determine the objective, starting form the minimal objective and step by step moving to objectives of higher levels. At the moment when an objective becomes feasible by all means it does not exist anymore and the next objective becomes minimal.

Daily planning of the class represent a high intellectual-cognitive activity by which the teacher determines the teaching purposes, sets the targets to be achieved, and evaluates the means that should be used for the class. Today's principles in various subjects are closely related to each other as general didactic and scientific principles, and also specific principles that make possible changes and innovation in the teaching process. Educational institution, according to Piaget is "to create minds that can be critical, can verify, and not to take for granted everything that is given".

\subsection{For a functional structure of the class}

In order for the teacher to achieve an effective class, should take into account the composition of the class during the determination of the objectives, and recognize at the best the affective side of the student. "To respect and promote the dignity of the child is one of the core values of our school. This is also for us the starting point of we can build a common vision and where we can focus our training program to our staff "(School of learning, Discipline fifth, page 149)

To achieve a practical understanding of a teaching structure should it be ERR or PNP we would stop and analyze in terms of all the services it can offer to the reorganization of the teaching process during a normal class in many ways, like:

- Formulation of objectives;

- Finding appropriate techniques for each objective;

- How to enable integration;

- The combination of communication skills within the subject and among subjects;

- Timeliness and finding the appropriate resources for each step of this structure. 
The teacher before building the class structure should:

Have correctly determined how long students will need to acquire new knowledge within an hour lesson.

What emotional state we will create to children while working with them?

Do the latter have the pleasure to be involved in this work and to easily adopt the proper values?

Is it the functional to use the target?

Can the student access in a wide interaction concepts and activities after the acquisition of this objective?

Effectiveness grow much more if it can be achieved to inter-relate better the teacher work with what students can do. We should emphasize that teaching objectives are not realized only because the teacher has them in mind, or have wrote them in the journal. "This kind of thinking affects the way you communicate with students. You can use several different teaching techniques (to suit different types of students) and you can create new challenges and difficulties with which the students will face, in order to overcome their limits. Through these methods students can also understand which are their strengths and weaknesses. Consequently due to this way of teaching, the school system constantly communicates with the student" (School of Learning, Discipline fifth, page 149)

We are considering as a model a class structure and all its components.

Table 1:

\begin{tabular}{|c|c|c|c|c|c|c|c|}
\hline Structure Phase & Objectives & $\begin{array}{l}\text { Strategies/ } \\
\text { Techniques }\end{array}$ & Relationship & $\begin{array}{c}\text { Skills that are } \\
\text { developed }\end{array}$ & Key Words & Time & Sources \\
\hline $\begin{array}{c}\text { Introduction / } \\
\text { Invocation: } \\
\text { Or Preparation for learning }\end{array}$ & $\begin{array}{c}\text { - e.g. } \\
\text { Distinguish names in a text } \\
\text { of } 5 \text { sentences }\end{array}$ & $\begin{array}{l}\text { Think/work in } \\
\text { pairs/ tell others }\end{array}$ & $\begin{array}{l}\text { Reading and } \\
\text { Language }\end{array}$ & $\begin{array}{l}\text { Reading, } \\
\text { Writing }\end{array}$ & $\begin{array}{l}\text { Name } \\
\text { gender } \\
\text { decline }\end{array}$ & $10^{\prime \prime}$ & $\begin{array}{l}\text { Text notebook } \\
\text { schedule }\end{array}$ \\
\hline $\begin{array}{c}\text { Understanding. Or } \\
\text { Construction of knowledge } \\
\text { (Content Processing) }\end{array}$ & $\begin{array}{c}\begin{array}{c}\text { Analyze characteristics of } \\
\text { the name forms during } \\
\text { decline }\end{array} \\
\end{array}$ & $\begin{array}{c}\text { Insert. } \\
\text { Table of concept }\end{array}$ & $\begin{array}{l}\text { Reading and } \\
\text { Language }\end{array}$ & $\begin{array}{l}\text { Reading, } \\
\text { Writing }\end{array}$ & $\begin{array}{l}\text { Name } \\
\text { gender } \\
\text { decline }\end{array}$ & $25^{c}$ & $\begin{array}{c}\text { Text } \\
\text { Video wall }\end{array}$ \\
\hline $\begin{array}{c}\text { Reflection } \\
\text { Or Reinforcement } \\
\text { (Consolidation of teaching) }\end{array}$ & $\begin{array}{l}\text { Compare the decline of } \\
\text { male from female names }\end{array}$ & Venn Diagram & $\begin{array}{l}\text { Reading and } \\
\text { Language }\end{array}$ & $\begin{array}{l}\text { Reading, } \\
\text { Writing }\end{array}$ & $\begin{array}{l}\text { Name } \\
\text { gender } \\
\text { decline }\end{array}$ & $10^{\prime}$ & Schedule \\
\hline
\end{tabular}

For every objective the teacher is required to find one or more techniques or strategies that he finds suitable in relation to relevant objectives. In the same way you should follow for each step of the table structure analyzing objectives, strategies, techniques, relationship, skills that are developed, keywords, time and the sources etc. The preparation of the Albanian language teacher for a class does not end here. Once the above table has been prepared it needs to be broken down all activities that will be carried out.

If we would like to breakdown the structure in stages and steps, it is worthwhile to make an additional comment about the closed relationship and interaction of the elements of teaching. Accordingly the breakdown of a class may be reflected by the following table:

Table 2:

\begin{tabular}{|c|c|c|c|}
\hline Steps & What will the teacher do? & What will the student do? & Tim \\
\hline $\begin{array}{l}\text { Think/work } \\
\text { in pairs/ } \\
\text { tell others }\end{array}$ & $\begin{array}{l}\text { Here will you develop all the activities that will make the teacher for the achievement of } \\
\text { the objective 1: } \\
\text {-Breakdown the objective through the technique that will be used which allows for a } \\
\text { combination of views. In order to achieve this technique the teacher writes or prepares } \\
\text { in advance some open questions and asks students to respond in writing to them... } \\
\text { The teacher puts students in pairs (two desk mate) } \\
\text { This technique makes students reflect on the text and to shape their opinions. } \\
\text { The teacher leads, directs, guides. } \\
\text { This step must be connected to the respective objective. If the connection is not done } \\
\text { the class is considered failed. }\end{array}$ & $\begin{array}{l}\text { Students follow the steps that they need to } \\
\text { follow according to the teacher recommendation. } \\
\text { Students in small groups of pairs prepare } \\
\text { questions and seek answers } \\
\text { Students are engaged in the learning activity. } \\
\text { To have more accurate answers students work } \\
\text { in pairs and try to achieve together as correct as } \\
\text { possible answers } \\
\text { Finally of each pair group is represented by a } \\
\text { discussion present their ideas about the answers } \\
\text { to the given questions. }\end{array}$ & 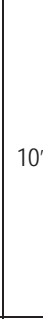 \\
\hline $\begin{array}{l}\text { Insert } \\
\text { Table of } \\
\text { Concept }\end{array}$ & $\begin{array}{l}\text { - The teacher distributes white sheets across working groups explaining how students } \\
\text { will act. } \\
\text { It is an analysis technique that promotes the analyses of concepts, facts, occurrence } \\
\text { and serves a lot in learning Albanian language, considering also aspects related to this } \\
\text { subject such as speaking, writing, grammar, etc. } \\
\text { The teacher talks, discusses, exchanges ideas by checking workgroups. } \\
\text {-The teacher manages, organizes coordinates, promotes, stimulates, and supports. } \\
\text { This step must be connected to the respective objective. If it is not connected the class } \\
\text { is considered tohave failed. }\end{array}$ & $\begin{array}{l}\text { Clearly define what the student will do. } \\
\text { Working groups work independently, among } \\
\text { them by discussing and arguing over class work }\end{array}$ & \\
\hline
\end{tabular}




\begin{tabular}{|c|c|c|}
\hline $\begin{array}{l}\text { Diagram } \\
\text { Venn }\end{array}$ & $\begin{array}{l}\text { The two questions on which to build the Venn diagram are: } \\
\text { 1-What are the similarities between...? } \\
\text { 2-What are the differences between them? } \\
\text { During this phase, the teacher listens carefully to students' responses, reacts positively } \\
\text { to any response by approving and objecting by students using incentives } \\
\text {-The teacher manages, organizes coordinates, promotes, supports and give tasks } \\
\text {-Teacher involves students in assessment and self-assessment. }\end{array}$ & $\begin{array}{l}\text { Students draw the Venn diagram highlighting the } \\
\text { similarities and differences of the part. They } \\
\text { refer, argue demonstrate and compare their } \\
\text { jobs. } \\
\text { Intensive involvement in this process brings a } \\
\text { spirit of cooperation among students }\end{array}$ \\
\hline
\end{tabular}

\subsection{Grouping techniques and strategies}

According to the literature and research in the field of using techniques and strategies we have achieved a sorting and grouping as below presented.

This grouping allows and provides for teachers an easy way in finding those techniques and strategies according to the aim used in the structure of the class. These techniques and strategies are not invented by us, but are researched and grouped by experimented projects, which have already been turned into real schools, in the practice of education in Albania. It is expected that teachers fit better with them and use them appropriately in the structure of a lesson. For this purpose, the following table provides help in placing them right during the teaching process.

Table 3: Grouping techniques and strategies according to the service they offer

\begin{tabular}{|l|l|l|l|l|}
\hline Research Techniques & Working Group & Asking in class & Writing & Reading \\
\hline Case Study & Discussion & Asking techniques & Two-party journal & INSERT \\
\hline Project & Small working group & DRTA/DLTA & Save the last word for me & Know/l want to know/Learn \\
\hline Excursion & Combining Techniques & Wall Exhibition & Kubimi & Concept table \\
\hline Survey & Think/ Work in pairs/ your friend & Author questions & Kllasteri & DRTA \& DLTA \\
\hline Experiment & Playing roles \& & Playing roles & Fiveverses & Groups \\
\hline Findings & -Group Experts & Exploration & Concept Table & Minilesson/ School newspaper \\
\hline Solution of the problem & & & & Wall Exhibition \\
\hline
\end{tabular}

\subsection{The sensitivity of teachers in using of techniques and strategies during the teaching process focusing on the student}

In connection with the use of techniques and strategies for teaching interactive we have communicated with teachers through a questionnaire. We have collected different opinions about their attitudes, regarding the use of these strategies and techniques nowadays, which guide the teaching process focused on the student.

\section{Teacher Qustionnaire}

\subsection{Content}

\begin{tabular}{|c|c|c|c|c|c|}
\hline 1. Description & $\begin{array}{l}\text { Not at } \\
\text { all }\end{array}$ & little & Average & Good & $\begin{array}{l}\text { Very } \\
\text { Good }\end{array}$ \\
\hline How much importance YOU give to the class structure? & 0 & 0 & $10 \%$ & $70 \%$ & $20 \%$ \\
\hline Does the teaching concept focusing on the student foster student creativity? & 0 & 0 & $10 \%$ & $40 \%$ & $50 \%$ \\
\hline Is it the teaching process focusing on student concept applicable to you? & 0 & 0 & $20 \%$ & $50 \%$ & $30 \%$ \\
\hline Does the application of these methods for you cause the increase of the learning goals? & 0 & 0 & $20 \%$ & $40 \%$ & $40 \%$ \\
\hline Student's results are ..? & 0 & 0 & $20 \%$ & $70 \%$ & $10 \%$ \\
\hline $\begin{array}{l}\text { Does the teaching methods and techniques enable the integration between different } \\
\text { subjects? }\end{array}$ & 0 & 0 & 0 & $40 \%$ & $60 \%$ \\
\hline Are the students active while using these techniques? & 0 & 0 & $0 \%$ & $30 \%$ & $70 \%$ \\
\hline Does the interaction with other subjects occurs? & 0 & 0 & $30 \%$ & $50 \%$ & $20 \%$ \\
\hline Do you have difficulty in using other techniques? & 0 & $30 \%$ & $40 \%$ & $20 \%$ & $10 \%$ \\
\hline Are you trained by specialist for the acquisition of these techniques? & 0 & $30 \%$ & $50 \%$ & $10 \%$ & $10 \%$ \\
\hline Do teachers use traditional methods? & 0 & $20 \%$ & $40 \%$ & $30 \%$ & $10 \%$ \\
\hline How many teachers use techniques according to the teaching structure? & 0 & & $30 \%$ & $40 \%$ & $30 \%$ \\
\hline Are these methods working with a large number of students? & 0 & $30 \%$ & $30 \%$ & $40 \%$ & $10 \%$ \\
\hline Do you have the material basis for the implementation of these methods? & 0 & $30 \%$ & $30 \%$ & $20 \%$ & $20 \%$ \\
\hline
\end{tabular}


2. In the following table, express the percentage of using the different phases of this table in the preparation of you journal?

\begin{tabular}{|c|c|c|c|c|c|c|c|}
\hline Structure phases & Objectives & Strategy/techique & Interaction & Developing expressions & Key words & Time & Sources \\
\hline $80 \%$ & $70 \%$ & $30 \%$ & $30 \%$ & $10 \%$ & $10 \%$ & $40 \%$ & $10 \%$ \\
\hline
\end{tabular}

\subsection{Analysis of the questionnaire}

Number of people interviewed: 50 teachers of elementary Schools system in the city of Tirana.

Of course the above questionnaire needs feedback from all teachers that implement the curriculum of teaching the Albanian language in schools. This is an experience that should remain open and be continuously enriched. Many years working productivity is significant and touchable.

Referring to statistics issued by the questionnaire, are clearly evidenced all the strengths and weaknesses of these interactive methods. Teachers say that: students are very active and interested in this way of working because they have complete freedom of thought and understanding. Also working in groups in the classroom creates playing roles and brings into another working environment. This way is encouraged critical thinking and understanding by students. All students are active, creative and engaged in providing ideas and opinions. They appreciate each other and express satisfaction with the application of new techniques, which are quite attractive for them. It has been noted that in implementing these new interactive teaching techniques, the main work is done by the students themselves. Students through numerous activities learn better the subject, being equal and collaborative with each other. However by knowing better the new techniques and strategies they can bring in return a great services in the learning field and can be used in all subjects.

As can ne noticed from the table the most positive results are in favor of the principle of integration, despite the reluctance or not acquisition of the innovation due to being attractive from the traditional methods. $50 \%$ of teachers have welcomed the introduction of new innovations, where the teaching process focused on the student increases their creativity.

Also it was noticed that older teachers have lost patience to use new techniques during the class. There are teachers who spend time talking about topics which fall out of curricular or about their personal experiences. Approximately $35 \%$ of teachers misinterpret the new methodology by allowing students to read on their own. $70 \%$ of them do not find the correct technique for adapting it to the subject target. $30 \%$ of teachers use appropriate and correct combination strategies. $40 \%$ subject teachers make fair distribution of time in the learning process by using the teaching process focused on student. $40 \%$ of teachers use a clear structure for teaching.

$70 \%$ of teachers do not select the correct teaching strategies according to the learning objective, despite that they are trying to include these techniques in their learning journal.

Teachers feel that by the use of these innovations is often difficult to manage teaching time, which lasts 45 minutes. Textbooks are not designed to work that way. Unfortunately the reading texts contain prominently story and fairytales with an extremely outdated moral, with pedagogical apparatus rather old, with vocabulary and language that belongs more to history and less to the one used today, those types of lecture texts, which make the student feel tired and develop just a little the fantasy and thought for the future.

Teachers say they do not have adequate cabinets and didactic teaching tools. Teachers say they in order to be motivated in their work there should in place occasional trainings in teaching methodology focused on the student, where teachers themselves should be stakeholders in the change process.

"The ultimate goal of change in education: teachers should see themselves as "stakeholders" who have put at risk something from their own process to the success of the system as a whole, by searching the meaning, as an unachievable key of this success." (Fullani, page 408)

\section{Results}

- Knowledge and application of contemporary models requires professional development for teachers and learning during all their life. It requires exchange of best practices in daily activities, sharing experiences.

- Improvement of teaching and learning requires new forms and professional skills.

- The teaching process focused on the student should provide didactic materials that help teachers in their work. 
- The education system requires motivated teachers who have a new mentality. To plan means to think in advance, to project, to draw exactly, the model, to design, to write etc.

- If we want to change the quality of teaching and learning we should concentrate our preparation for the class toward finding these solutions. In the journal models is found the contemporary teaching model. The student thinks, works, evokes, builds, designs, draws, solves problems, compares, analyzes, collaborates with his fellow in the group, refers, argues, and learns.

- Open Teaching model - the process in which the students and the teacher must be both at the same time authors and actors in applying a teaching type, where the roles of the two parties appear more diverse.

- Never should be underestimated the new updates that the student brings during a class, because their individual work period is the biggest achievement for all their hard work and not to forget that these works make the class interesting.

- The teacher should become a positive role model, to be followed by students in the correct use of standard language.

\section{References}

MASH. (2012). Effective teaching and learning. (Curriculum framework of elementary school, P. 21). Tirana

MASH. (2012). (Curriculum framework of elementary school. P. 22). Tirana

Fullan, M. (2001). The New Meaning of Educational Change. (Edualba. 3rd edition. P. 230, P.194). Tirana

Gjokuta M. (2009). The didactic of Albanian language. (SHBLU publisher. P. 263.266). Tirana

Piaget, J. (2005). On the pedagogy. (Publication of Institute of Research and Standards. P.10).Tirana

Piaget, J. (2005). On the pedagogy. (Publication of Institute of Research and Standards. P.14). Tirana

Senge, P. Nelda, C. Timothy, L. Bryan, S. Janis, D. Art, K. School of Learning. (Publishing \& Printing House Kristalina-KH. Publication of Institute of Pedagogy Studies. The Fifth Discipline. P 149,408) 